\title{
Trends in the global organoid technology and industry: from organogenesis in a dish to the commercialization of organoids
}

\author{
Hanbyeol Lee, Jeong Suk Im, Da Bin Choi, Dong-Hun Woo \\ Department of Commercializing Stem Cell Technology, NEXEL Co., Ltd., Seoul, Korea
}

Received: May 31, 2021

Revised: June 25, 2021

Accepted: July 2, 2021

Correspondence to:

Dong-Hun Woo, PhD

Department of Commercializing Stem

Cell Technology, NEXEL Co., Ltd., 8th

floor, 55 Magokdong-ro, Gangseo-gu,

Seoul 07802, Korea

E-mail:dhwoo@nexel.co.kr

\begin{abstract}
Animal models have been standard methods for non-clinical research in drug development for decades. However, many drugs that have shown satisfactory results in non-clinical studies have failed in the clinical stage, presumably because animal data are not fully convertible to human data. Human organoid technology has recently been considered as an alternative to existing non-clinical testing methods, and it could potentially serve a role as a bridge from non-clinical to clinical trials, compensating for the current limitations arising from non-clinical animal models. For this reason, organoid technology is being utilized in various fields of research including academic studies, disease modeling, drug screening, biobanks, and regenerative medicine. In addition, as organoid technology progressively develops, it has been combined with bioengineering to develop applications from manufacturing to drug evaluation platforms, which is leading to a demand for commercialization of organoids for researchers. In accordance with this global trend, the organoid industry continues to grow throughout the world, and organoid research and the market for organoids have been boosted by the demand for efficient and rapid drug development in response to the coronavirus disease 2019 pandemic. In this review, we discuss recent global trends in organoid research, based on tissue types and applications, as well as the organoid market and its prospects.
\end{abstract}

Keywords: Organoids; Stem cells; Cell Culture Techniques; Drug evaluation

\section{Introduction}

With recent advances in biomedical sciences, there have been many non-clinical trials using experimental animals to predict the effects of drugs, cosmetics, and chemicals. However, despite the utility of experimental animals, limitations in the accuracy of animal testing and associated ethical issues have given rise to the development of non-clinical tests using human cell sources. At present, organoid technology holds massive potential for biomedical applications including disease modeling, drug screening, biobanks, regenerative therapy, genetic screening, and personal- ized medicine $[1,2]$. Demand for organoid technology for in vitro toxicity and efficacy testing is also increasing in the pharmaceutical and cosmetic industries, leading to increasing demand for the commercialization of organoid technology in the life science industry.

An organoid is a miniature, self-organized, three-dimensional (3D) structure composed of tissues derived from various sources including tissues and stem cells. These cultures can be crafted to replicate a simplified version of a complex organ, or to express specific characteristics to produce certain types of cells. Since organoid technology has become an independent field of

Copyright (C) 2021 The Organoid Society

This is an Open Access article distributed under the terms of the Creative Commons Attribution Non-Commercial License (http://creativecommons.org/licenses/bync/4.0/) which permits unrestricted non-commercial use, distribution, and reproduction in any medium, provided the original work is properly cited. 
research, a precise understanding of organogenesis in a dish will be a significant factor for the research and use of tissue or stem cell-derived organoids [3]. Since the 1900s, many scientists have agonized over the concept of the 3D architecture of organoids to establish the optimal conditions for the cellular composition and relationships in tissues observed in vivo. After the 2000s, organoids have been regarded as 3D structures growing from stem cells and consisting of organ-specific cell types that self-organize with spatially restricted lineage commitment [4]. Notably, Sato et al. [5] developed a sophisticated interstitial organoid resembling a crypt-villus structure in 2009. This finding became the spark for further developments in organoid research, leading to successful application in cultures of other tissue types such as stomach, pancreas, liver, colon, brain, lung, and heart from human tissue or pluripotent stem cells (PSCs) [6].

The recent pandemic of coronavirus disease 2019 (COVID-19), which is caused by severe acute respiratory syndrome coronavirus 2 (SARS-CoV-2) has been a life-threatening crisis for all populations across the globe, but has ironically had a positive impact on the organoid market. Since organoids could accelerate translational research from non-clinical trials to clinical trials of drug development, studies with several tissue-specific organoids have demonstrated the value of organoids as a research platform for understanding the pathophysiology of COVID-19 in the body [7], and for evaluating the efficacy of drug or vaccine candidates [8].

In this review, we present not only insights into the state-of-theart global trends of human organoid research and the organoid market, but also trends in the global organoid market and the factors driving the market. Moreover, the impact of the COVID-19 pandemic on global organoid research and market is analyzed as well.

\section{Current state of global organoid research and technology}

To investigate progress in global organoid research, PubMed publications on organoid research from 2010 to 2021 were analyzed. The results showed that the number of publications dramatically increased from the mid-2010s, and studies using stem cell-derived organoids have also increased significantly during the same period (Fig. 1).

\section{Stem cell and organoid research}

Among various cell sources for organoid generation, stem cells are considered the most promising because stem cells could easily mimic human development or organ regeneration in vitro with their self-renewal and differentiation potency. Furthermore, recent advances in gene editing technology (e.g., the CRISPR/Cas9 system) have facilitated disease modeling in stem cells by the correction or insertion of certain mutations.

Organoids could be established from PSCs or multipotent adult tissue (normal tissues or tumor tissues)-derived stem cells (adult stem cells [ASCs]). They make up organ-specific cell types that can spontaneously self-organize by forming clusters of cells, and these clusters spatially undergo finite lineage commitment to generate 3D cell assemblies that mimic the cellular compositions, architecture, and functions of the relevant organs $[3,9]$. The advantages and disadvantages of each stem cell source for organoid formation are summarized in Fig. 2.

Massive productivity is the biggest advantage of using PSCs in organoid generation based on embryonic stem cells (ESCs) and induced PSCs (iPSCs)' unlimited potential for proliferation and differentiation [2]. Furthermore, organoids from PSCs could be easily generated at a uniform size in vitro. A given number of PSCs

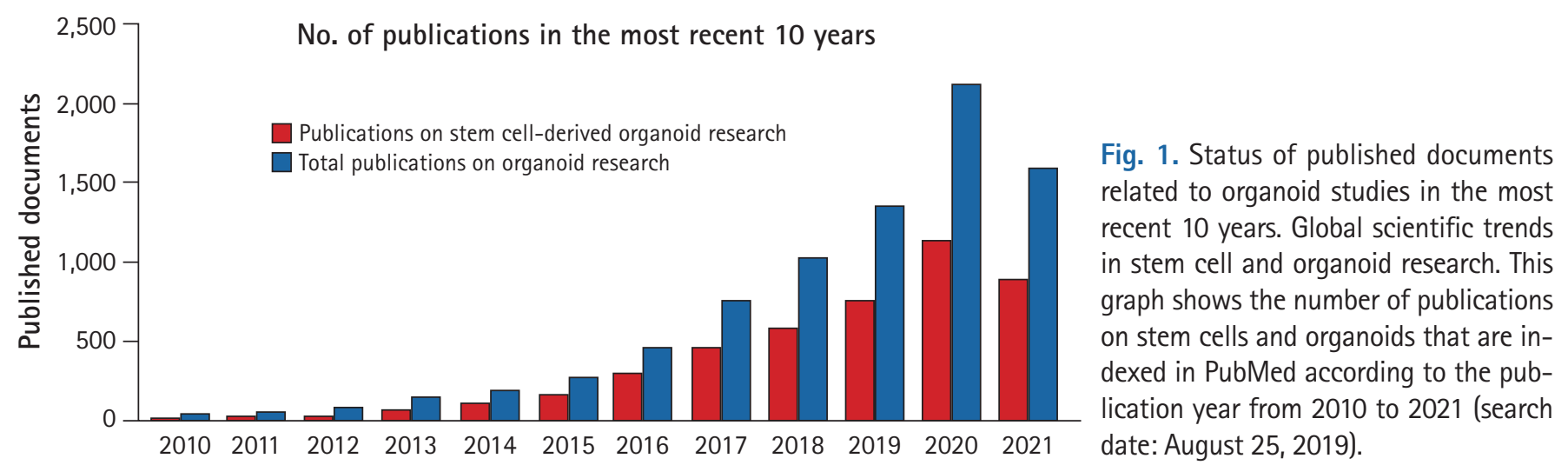

Publication year 
PSCs

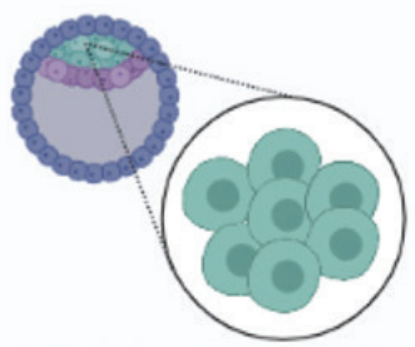

ESCs

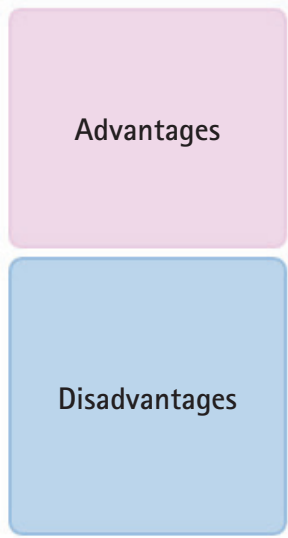

- Readily obtainable in large numbers

- Heterogeneity of cell type to mimic the native organ

- Unintentional heterogeneity owing to off-target

differentiation

- Often less mature form

- Ethical concerns

Primary tissue cells (via biopsy)

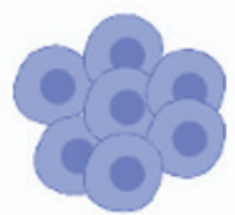

iPSCs

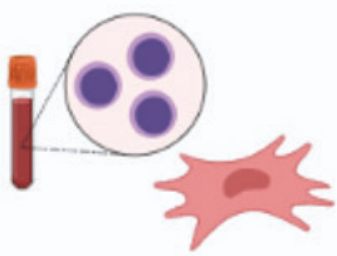

ASCs
- Readily obtainable in large numbers, especially patientspecific

- Heterogeneity of cell type to mimic the native organ

- Unintentional heterogeneity owing to off-target differentiation

- Often less mature form

- Use of oncogenes for reprogramming
- Heterogeneity of cell type to mimic the native tissue

Difficult isolation

- Limited differentiation potential

Fig. 2. Characteristics of stem cell sources for organoid research. The initial cell sources used for organoid culture can be pluripotent stem cells (PSCs), including embryonic stem cells (ESCs), induced PSCs (iPSCs), and human adult stem cells (ASCs). Each cell type has associated advantages and disadvantages as a source for organoids. Each type of organoid develops with unique morphological and physiological features, and the process of developing organoids from PSCs optionally involves the presence of mesenchymal niches, in contrast with ASCs.

first allows expansion and easily generates uniform PSC aggregate-like 3D structures with appropriate devices or platforms [10], and then, the uniform 3D PSC aggregates could go through several processes designed to mimic a series of developmental signaling networks that lead to differentiation into the specific cell types of interest in a dish with uniformly sized organoids. A PSC-derived organoid could also have a multicellular composition, constituting another advantageous feature of PSC-derived organoids. For example, single-cell RNA transcriptomes of kidney organoids from PSCs consist of $10 \%$ to $20 \%$ non-renal cells such as neuronal cells or muscle cells [11]. Although this result might be attributed to off-target differentiation with undesired downstream consequences, it implies the possibility of generating multicellular organoids that mimic the native organs from PSCs without a mixture of different cell types in culture. However, PSC-derived organoids often show gene expression patterns that are closer to those of fetal tissues than those of their adult counterparts $[12,13]$. For these reasons, current organoid technology from human PSCs might only be useful for studying early organogenesis in human developmental biology, and this limitation must be overcome to expand the applications of PSC-derived organoids.

In a standard establishment of human ASC-derived organoids, single stem cells or small cell clusters obtained from a biopsy of adult tissues (including tumors) are placed in a 3D matrix with a cocktail of growth factors mimicking essential aspects of the niche in which the cells usually reside [14]. Unlike PSC-derived organoids, ASC-derived organoids consist of a well-defined and homogeneous structured cell population mainly found in the epithelium. In a landmark study published by the research group of Dr. Hans Clevers, complex 3D organized crypt-villus structures, which are now considered the first organoid, were generated from seeding of single intestinal stem cells [5]. Unlike iPSC-derived organoids, these organoids can be directly generated from dissected adult tissue fragments including diseased patient tissues. It has subsequently been reported that human ASC-derived organoids can be established from various tissue sources, including intestine, 
colon, liver, pancreas, stomach, lung, bladder, mammary gland, endometrium, prostate, fallopian tube, and others [2]. However, although it is easy to obtain all potentially necessary ASCs for organoid culture, human ASC-derived organoids normally have limitations in their differentiation potential and lifespan due to the restricted culture conditions for a specific tissue type [15].

In summary, PSCs are useful to explore early organogenesis in the developmental process and to differentiate the desired tissues in a dish, while organ-specific ASC-derived organoids are useful for adult tissue biology. Therefore, researchers could select the appropriate stem cell source suitable for their applications in diverse domains of biomedical research.

\section{Main organoid types in current research}

Currently, stem cell-derived organoids are established from the differentiation of stem cells cultured in a specialized microenvironment that aids the developmental process of certain tissues. Below, we present cases of generating each lineage-derived organoids from stem cells.

Research on ectoderm lineage-derived organoids has mainly focused on brain types. Lancaster et al. [16] reported the first self-assembled cerebral organoids, and subsequent studies established human PSC-derived brain-region-specific organoids, including the forebrain, choroid plexus, hippocampus, radial glial cell, midbrain, hypothalamus, and retina [17]. Furthermore, assembloids such as integrated human forebrain spheroids established from the fused form of dorsal and ventral forebrain organoids or thalamic and cortex organoids have also been reported [18]. Assembloids are a type of advanced technology in brain organoid research because they could facilitate the modeling of interactions between different brain regions and studying the assembly of neural circuits. In addition to brain organoids, other established types of ectodermal lineages such as skin organoids [19], inner ear organoids [20], and salivary gland organoids [21] have been reported. Further information on research on ectodermal lineage-derived organoids is described in Table 1 [20-46].

In the mesoderm lineage, the tissue type that has attracted the most interest is the circulatory system, including the kidney, heart, and vasculature. Takasato et al. [22,23] generated kidney organoids composed of renal interstitium and endothelium, and a kidney disease model in PSC-derived kidney organoids by gene editing was also reported [24]. Self-organizing chamber-like cardiac organoids from human PSCs [25] and murine heart organoids with multicellular compositions have also been established [47]. Cardiac organoids would be a leading tool for cardiac disease modeling and screening for cardiotoxicity [26,27]. Blood vessel organoids are a noteworthy area in vasculopathy. An article published in a prominent journal has reported the generation of blood vessel organoids in humans and mice [28], which addressed engineering of their perfusable in vitro vasculature system using chip technology to satisfy metabolic demands during development [29]. Table 1 presents further information on research on the mesodermal lineage-derived organoids.

In the endoderm lineage, a wide range of foregut-, midgut-, and hindgut-derived organoids have been reported. Lung organoids are the representative foregut lineage-derived organoids, and human PSC-derived lung organoids have been interconnected by a surprisingly delicate structure, including an upper airway-like epithelium with basal cells and ciliated cells, as well as a lower alveolar-like domain [30]. Notably, lung organoids have recently been used in models of SARS-CoV-2 infection in the respiratory tract [31]. Midgut- and hindgut-derived intestinal organoids were also generated from Lgr5 ${ }^{+}$stem cells, and further studies revealed that WNT3A and FGF4 signaling were involved in the generation of intestinal and colon organoids having villus and crypt-like structures [32,48]. Gjorevski et al. [49] identified that high stiffness of the matrix enhanced the expansion of intestinal organoids. Further information on research on the endodermal lineage-derived organoids is also described in Table 1 .

\section{Current applications of organoid research}

Human organoids have diverse applications ranging from basic research to drug development. Here, we provide a comprehensive overview of the current applications of human organoids.

\section{1) Studying tissue development}

The distinct mechanisms of autonomous self-organization in tissue development, homeostasis, and regeneration in organoid models have been verified [2]. Thus, organoids could provide simple and easily accessible mini-organ systems for studying contributory factors related to complex morphogenesis. For instance, fetal pulmonary organoids have used to determine the signaling interplay between fibroblast growth factors and the vascular endothelial growth factor A pathway for endothelial network formation and the role of the sonic hedgehog pathway in epithelial and endothelial morphogenesis [50]. Moreover, organoids have provided a tool for discovering essential factors of stem cell differentiation [6,51]. For example, human adult crypt-derived Lgr5 ${ }^{+}$ stem cells could re-establish intestinal epithelia in the absence of a mesenchymal compartment in a dish [5], although the interaction between intestinal epithelium and mesenchymal cells has been considered as an essential factor for intestinal morphogenesis [52]. Similar to intestinal organoid research, it was determined that the autonomous morphogenesis in optic cup organoids from PSCs 
Table 1. Current established organoid research by cell source and cell type

\begin{tabular}{|c|c|c|c|c|c|}
\hline Type & Cell type & Source & Key feature & Application & Ref \\
\hline \multirow[t]{10}{*}{ Ectoderm } & \multirow{3}{*}{$\begin{array}{l}\text { Optic cup, vesicle and } \\
\text { retina organoid }\end{array}$} & $\mathrm{hESCS}$ & - Formation of optic cup & - Developmental biology & {$[33,41]$} \\
\hline & & hiPSCs & - Formation of rod and cone cells & - Disease modeling & \\
\hline & & & - RPE-to-NR-transition & $\begin{array}{l}\text { - Biobanks for academic } \\
\text { studies }\end{array}$ & \\
\hline & \multirow{2}{*}{$\begin{array}{l}\text { Brain organoid and } \\
\text { forebrain spheroids } \\
\text { (brain assembloid) }\end{array}$} & $\begin{array}{l}\text { hESCs } \\
\text { hiPSCs }\end{array}$ & $\begin{array}{l}\text { Formation of cerebral cortical neurons, forebrain, } \\
\text { hippocampus, radial glial cells }\end{array}$ & $\begin{array}{l}\text { - Developmental biology } \\
\text { - Disease modeling }\end{array}$ & \multirow[t]{2}{*}{ [35-37] } \\
\hline & & & $\begin{array}{l}\text { - Modeling human microcephaly, Timothy syndrome, } \\
\text { and ZIKV infection }\end{array}$ & - Drug screening & \\
\hline & \multirow[t]{3}{*}{ Skin organoid } & hESCs & \multirow{2}{*}{$\begin{array}{l}\text { Formation of epidermis and dermis layer capable of } \\
\text { developing new hair follicle }\end{array}$} & - Developmental biology & \multirow[t]{3}{*}[42]{} \\
\hline & & hiPSCs & & - Regenerative medicine & \\
\hline & & & $\begin{array}{l}\text { - Formation of nascent mechanosensitive tough } \\
\text { complexes of sensory neurons and Schwann cells that } \\
\text { target Merkel cells }\end{array}$ & - Omics profiling & \\
\hline & \multirow[t]{2}{*}{ Inner ear organoid } & \multirow[t]{2}{*}{ hESCS } & - Formation of sensory epithelia & \multirow[t]{2}{*}{ - Developmental biology } & \multirow[t]{2}{*}{ [20] } \\
\hline & & & $\begin{array}{l}\text { Formation of vestibular-like hair cells with } \\
\text { electrophysiological properties similar to those of } \\
\text { native sensory hair cells }\end{array}$ & & \\
\hline \multirow[t]{2}{*}{$\begin{array}{l}\text { Surface } \\
\text { ectoderm }\end{array}$} & \multirow[t]{2}{*}{ Salivary gland } & \multirow[t]{2}{*}{ hASCs } & $\begin{array}{l}\text { - Developed ductal structures and mucin-expressing } \\
\text { acinar-like cells }\end{array}$ & \multirow[t]{2}{*}{$\begin{array}{l}\cdot \text { Developmental biology } \\
\cdot \text { Regenerative medicine }\end{array}$} & \multirow[t]{2}{*}{ [21] } \\
\hline & & & $\begin{array}{l}\text { Formation of salivary glands in vivo within the mouse } \\
\text { embryonic salivary gland mesenchyme }\end{array}$ & & \\
\hline \multirow[t]{10}{*}{ Mesoderm } & \multirow[t]{3}{*}{ Kidney organoid } & \multirow[t]{3}{*}{$\begin{array}{l}\text { hESCs } \\
\text { hiPSCs }\end{array}$} & $\begin{array}{l}\text { - Formation of metanephric and epithelial nephron } \\
\text { progenitors }\end{array}$ & - Developmental biology & \multirow[t]{3}{*}{ [22-24] } \\
\hline & & & $\begin{array}{l}\text { Use of human kidney organoids for the evaluation of } \\
\text { nephrotoxicity }\end{array}$ & - Drug toxicity & \\
\hline & & & - Modeling of polycystic kidney disease & & \\
\hline & \multirow[t]{4}{*}{ Cardiac organoid } & \multirow[t]{4}{*}{$\begin{array}{l}\text { hESCs } \\
\text { hiPSCs }\end{array}$} & $\begin{array}{l}\text { - Confirmation of regenerative capacity of immature } \\
\text { human heart tissue }\end{array}$ & $\begin{array}{l}\text { - Developmental biology } \\
\text { - Disease modeling }\end{array}$ & \multirow[t]{4}{*}[25-27]{} \\
\hline & & & $\begin{array}{l}\text { - Formation of cardiac organoid similar to human fetal/ } \\
\text { neonatal heart tissue }\end{array}$ & - Drug screening & \\
\hline & & & - Modeling regenerative response following cryoinjury & - Omics profiling & \\
\hline & & & $\begin{array}{l}\text { - Modeling of myocardial infarction and genetic } \\
\text { cardiomyopathy }\end{array}$ & & \\
\hline & \multirow[t]{3}{*}{ Blood vessel organoid } & \multirow{3}{*}{$\begin{array}{l}\text { hESCs } \\
\text { hiPSCs }\end{array}$} & - Exhibition of morphological, functional and molecular & - Transplantation & \multirow[t]{3}{*}[28,29]{} \\
\hline & & & $\begin{array}{l}\text { DLL4 and NOTCH3 as key drivers of diabetic } \\
\text { vasculopathy in blood vessels }\end{array}$ & & \\
\hline & & & - Vascularized organoids on a chip & & \\
\hline \multirow[t]{8}{*}{ Endoderm } & \multirow[t]{3}{*}{ Lung organoid } & \multirow{3}{*}{$\begin{array}{l}\text { hESCs } \\
\text { hiPSCs, hASCs }\end{array}$} & $\begin{array}{l}\text { - Formation of engraftable alveolar and airway-like } \\
\text { structures through basal, ciliary, and secretory cells }\end{array}$ & - Developmental biology & \multirow[t]{3}{*}[30,31,38]{} \\
\hline & & & - Modeling of cystic fibrosis & - Drug screening & \\
\hline & & & - Modeling of SARS-CoV-2 infection & Omics profiling & \\
\hline & Liver organoid & hiPSCs, hASCs & $\begin{array}{l}\text { Formation of a more complete 3D hiPSC-LB organoid } \\
\text { by HUVEC and mesenchymal cell co-culture }\end{array}$ & $\begin{array}{l}\cdot \text { Regenerative medicine } \\
\cdot \text { Disease modeling }\end{array}$ & [43] \\
\hline & & & - Modeling of SARS-CoV-2 infection & Omics profiling & \\
\hline & & & $\begin{array}{l}\text { - Modeling of } \alpha 1 \text {-antitrypsin deficiency and Alagille } \\
\text { syndrome }\end{array}$ & & \\
\hline & Gastric organoid & hESCs & - Modeling of human gastric cancer and Helicobacter & - Developmental biology & [34] \\
\hline & & $\begin{array}{r}\text { hiPSCs human } \\
\text { primary cells }\end{array}$ & $\begin{array}{l}\text { Differentiation of gastric organoids into mucous and } \\
\text { endocrine cell lineages }\end{array}$ & $\begin{array}{l}\cdot \text { Disease modeling } \\
\cdot \text { Omics profiling }\end{array}$ & \\
\hline
\end{tabular}


Table 1. Continued

\begin{tabular}{|c|c|c|c|c|c|}
\hline Type & Cell type & Source & Key feature & Application & Ref \\
\hline & Pancreatic organoid & $\begin{array}{l}\text { hESCs human } \\
\text { primary cells }\end{array}$ & $\begin{array}{l}\text { - Formation of ductal and acinar cells similar to human } \\
\text { fetal pancreas } \\
\text { - Modeling of ductal pancreatic cancer }\end{array}$ & $\begin{array}{l}\cdot \text { Developmental biology } \\
\cdot \text { Disease modeling } \\
\cdot \text { Omics profiling }\end{array}$ & [44] \\
\hline & Intestinal organoid & $\begin{array}{l}\text { hESCs } \\
\text { hiPSCs human }\end{array}$ & $\begin{array}{l}\text { - Formation of characteristic villus and crypt-like } \\
\text { structure }\end{array}$ & $\begin{array}{l}\text { - Developmental biology } \\
\text { - Regenerative medicine }\end{array}$ & $39,40,45]$ \\
\hline & & primary cells & $\begin{array}{l}\text { - Modeling of congenital loss of intestinal } \\
\text { enteroendocrine cells }\end{array}$ & - Disease modeling & \\
\hline & & & $\begin{array}{l}\text { - Production of CRISPR-Cas9-mediated CFTR-repaired } \\
\text { intestinal organoid }\end{array}$ & & \\
\hline & & & $\begin{array}{l}\text { - Hydrogel-delivered human intestinal organoids could } \\
\text { heal colon wounds }\end{array}$ & & \\
\hline & Colon organoid & $\mathrm{hESCS}$ & - Modeling of colorectal cancer & - Developmental biology & [32] \\
\hline & & $\begin{array}{l}\text { hiPSCs, hASCs } \\
\text { human primary } \\
\text { cells }\end{array}$ & $\begin{array}{l}\text { - Mimicking of colonic crypts } \\
\text { - Contributes to colonic epithelium regeneration }\end{array}$ & $\begin{array}{l}\cdot \text { Regenerative medicine } \\
\cdot \text { Disease modeling }\end{array}$ & \\
\hline & Prostate organoid & hASCs & $\begin{array}{l}\text { - Formation of prostate organoid exhibiting functional } \\
\text { androgen receptor signaling }\end{array}$ & $\begin{array}{l}\cdot \text { Developmental biology } \\
\text { - Disease modeling }\end{array}$ & [46] \\
\hline & & & $\begin{array}{l}\text { - Formation of architecture containing luminal and } \\
\text { basal cell }\end{array}$ & & \\
\hline & & & - Modeling of prostate cancer & & \\
\hline
\end{tabular}

hESCs, human embryonic stem cells; hiPSCs, human induced pluripotent stem cells; RPE, retinal pigment epithelium; NR, neural retina; ZIKV, Zika virus; hASCs, human adult stem cells; SARS-CoV-2, severe acute respiratory syndrome coronavirus 2; 3D, three-dimensional; LB, liver bud; HUVEC, human umbilical vein endothelial cells.

did not require signals from an overlying surface ectoderm [33]. Organoids also facilitate knockout studies of essential genes that would not be feasible in vivo due to embryonic lethality, enabling in-depth research into the role of genes implicated in human genetic disorders.

\section{2) Disease modeling}

Unlike traditional 2D cell cultures, organoids could mimic human pathologies at the organ level and provide an effective model for human translational studies to develop practical applications of scientific discoveries in human diseases.

Firstly, human organoids could reproduce host-pathogen interactions in vitro. Human gastric organoids were used to study Helicobacter pylori infection by mimicking the virus infection in the stomach [34]. Zika virus infections were also investigated in brain organoids $[35,36]$, and various chemicals that could mitigate the hypomorphic effect of Zika virus were discovered in the studies using Zika virus-infected human brain organoids [37]. In studies of intestinal infections, norovirus and rotavirus have been successfully grown in human intestinal organoid cultures $[53,54]$, and infections of Salmonella typhi and Clostridium difficile, major intestinal bacterial pathogens, were also reproduced in cultured intestinal organoids $[55,56]$. More recently, organoids have provided valuable research tools in response to the SARS-CoV-2 pathogen. Several reports have successfully shown that SARSCoV-2 could be infected and propagated in the primary human liver and gut organoids, as well as in PSC-derived blood vessel and kidney organoids [38,57,58]. Furthermore, COVID-19 pathogenesis was verified in organoids, and researchers have found that the viral receptor, angiotensin-converting enzyme 2, is the mechanism of entrance of SARS-CoV-2 into host cells, and that the pathogen could infect other tissues beyond the lung [59]. As seen in previous studies, the feasibility of organoids as effective infectious disease models in vitro has been well demonstrated, and they could be used as novel screening platforms to discover drugs against various infectious diseases. Further information on research that used organoids for infectious disease is described in Table 2 [12,31,53-57,60-63].

Human organoids also play a role in enhancing our understanding of human cancers because organoids recapitulate the information of the parental patients. Diverse ASCs from cancer patients have been cultured as cancer organoids [64], and to date, organoid biobanks have been acquired by cancer patient's tissues, including breast, lung, glioblastoma, neuroendocrine, kidney, gastric, liver, pancreas, bladder, prostate, and colon [65]. The biobank of cancer organoids has shifted the study of cancers to investigate the identification of predictive biomarkers and tumor pathophysiology such as mechanisms of metastasis, chemosen- 
Table 2. Organoids used for infectious disease modeling

\begin{tabular}{|c|c|c|c|c|}
\hline Type & Organoid & Cell source & Pathogen & Ref \\
\hline \multirow{14}{*}{ Virus } & Brain & PSCs & - Zika virus & [60] \\
\hline & & & - Japanese encephalitis virus & \\
\hline & & & - SARS-CoV-2 & \\
\hline & Liver & PSCs & - Hepatitis B virus & [61] \\
\hline & & ASCs & & \\
\hline & Intestine & PSCs & - Human norovirus & {$[53,54]$} \\
\hline & & ASCs & - Rotavirus & \\
\hline & & & - SARS-CoV-2 & \\
\hline & Kidney & ASCs & - BK virus & {$[57,62]$} \\
\hline & & & - SARS-CoV-2 & \\
\hline & Respiratory tract & PSCs & - Respiratory syncytial virus & [31] \\
\hline & & ASCs & - Influenza virus & \\
\hline & & & - Enterovirus 71 & \\
\hline & & & - SARS-CoV-2 & \\
\hline \multirow[t]{5}{*}{ Bacterium } & Intestine & PSCs & - Salmonella typhi & {$[55,56]$} \\
\hline & & ASCs & - Clostridium difficile & \\
\hline & Stomach & PSCs & - Helicobacter pylori & [12] \\
\hline & & ASCs & & \\
\hline & Respiratory tract & ASCs & - Clostridium difficile & [56] \\
\hline \multirow[t]{6}{*}{ Parasite } & Liver & PSCs & - Plasmodium & [63] \\
\hline & & ASCs & & \\
\hline & Intestine & PSCs & - Cryptosporidium & [56] \\
\hline & & ASCs & & \\
\hline & Respiratory tract & PSCs & - Cryptosporidium & [56] \\
\hline & & ASCs & & \\
\hline
\end{tabular}

PSCs, pluripotent stem cells; SARS-CoV-2, severe acute respiratory syndrome coronavirus 2; ASCs, adult stem cells.

sitivity of anti-cancer drugs, and tumor-immune cell interactions [66]. Furthermore, drug development workflows have been developed through high-throughput processes [65,67].

Finally, human organoids are available as a novel platform for exploring genetic diseases. Apart from the well-known genetic diseases, The Genome Aggregation Database has reported 4.6 million missense variants for disease-causing mutations [68]. However, only $2 \%$ of mutations have shown clinical interpretations from in vitro functional assays and transgenic mice, which often failed to describe disease outcomes in human patients. Therefore, an alternative approach for studying genetic diseases is required, and organoids could fulfill this goal. Schwank et al. [39] first manufactured gene-corrected intestinal organoids derived from biopsies of 2 different cystic fibrosis (CF) patients with a homozygous CFTR F508 deletion using CRISP-Cas9 technology, and later studies generated CF patient-derived iPSCs with their homozygous mutations corrected by CRISPR, and the resultant corrected iPSC-derived organoids showed the capacity to differentiate into airway epithelium with normal CFTR expression and function [69]. Yang et al. [70] also assessed the abnormal contractile functions resulting from a myosin heavy-chain $7 \mathrm{mu}-$ tation (E848G) in familial cardiomyopathy using patient-specific iPSC-derived cardiac organoids and proved that gene correction in the iPSC-derived organoids with dystrophin mutations could be applicable to tissue replacement therapy [71]. Thus, genetic disease modeling using organoid technology is a useful tool for functional studies of certain mutations and potential therapeutic strategies for clinical management.

\section{3) Drug screening}

Disease modeling using organoids has naturally been linked with drug screening in the drug development process. Currently, high-throughput drug screening has been studied extensively in the field of cancer organoids. Kita et al. [72] analyzed approximately over 2,000 compounds in bladder cancer organoid lines, and they found that disulfiram, an anti-alcoholism drug, showed potential for use against bladder cancer as well. Lampis et al. [73] also found the hypersensitivity to HSP90 inhibitors in 
MIR21-mutated cholangiocarcinoma. Cancer organoids could also be useful in screening for effective drugs in cancer patients. For example, colorectal cancer patients with different mutations have shown different responses to EZH2 inhibitors. Moreover, screening with colorectal cancer organoids has been successful in determining that organoids with ATRX and $P A X 2$ mutations showed sensitivity against EZH2 inhibitors. In contrast, p53 mutation-bearing organoids were resistant to EZH2 inhibitors [74]. Moreover, the United States Food and Drug Administration has recently adopted an "organ-on-achip" system to screen for organ-specific or multi-organ toxicity of drugs, food additives, chemicals, cosmetics, and other compounds [75]. The use of organoid platforms for drug toxicity and safety testing might also be expended because of their effectiveness.

\section{4) Regenerative medicine}

Modern medicine has presented limited tissue supplies from healthy donors for tissue transplantation in many incurable diseases $[1,3]$. In this respect, organoid-based regenerative medicines have promising potential as an alternative approach to cell replacement therapies. Transplantation of kidney organoids in a mouse model resulted in vascularization of the mouse kidney with the formation of renal tubules [23], and intestinal organoid transplantation in a murine model resulted in colon regeneration [40]. Orthotopic transplantation of liver organoids demonstrated that human fetal hepatocyte organoids displayed high engraftment efficiency in a toxin-induced acute liver failure mouse model [76]. Human iPSC-derived glucose-responsive islet-like organoids generated endocrine-like cell types with the re-establishment of glucose homeostasis upon transplantation in diabetic NODSCID mice [77]. Furthermore, 3D bioprinting technology has been suggested as a new strategy to build a 3D tissue architecture for the use of organoids in regenerative medicine. Zhang et al. [78] successfully devised endothelialized myocardium and heart-on-achip using bioprinting, and additional studies have continued to be reported on the combination of $3 \mathrm{D}$ engineered and organoid technology to mimic the structures of real organs and to provide transplantable mini-organs [79].

Although dedicated efforts are required to apply organoids for therapeutic purposes, including enhancing integrity after transplantation and developing alternative animal-free synthetic matrices for clinical applications [80], organoids are undoubtedly an interesting model for the development of effective regenerative medicines.

\section{Current state of the organoid market and commercialization}

\section{Overview of the global organoid market}

Several experts in the science industry are forecasting that the global organoid market is marching forward at a rapid pace for the forecast period of 2020 to 2027 and is anticipated to reach 3,420.49 million United States dollars by 2027 with a compound annual growth (CAGR) of $21.7 \%$ [81,82]. The key factors driving the market are therapeutic and diagnostic models as alternatives to animal models, efforts in academia to adopt novel technologies, growing industry-academia collaborations for R\&D, and advanced technology in 3D engineering. Another factor is an increase in the incidence and prevalence of infectious diseases with rapid changes in the environment (with the most recent example being the COVID-19 pandemic), and the application of organoids as therapeutic tools for COVID-19.

Based on organ types, the highest market share as of 2019 was for intestine organoids, followed in descending order by liver, stomach, pancreas, lung, kidney, and other organoids (Fig. 3). According to a market research report by an integrated market research platform, even though the intestinal segment captured the largest share of the global organoid market in 2019, the forecast for 2027 predicts that liver segment will hold the largest market share and that the kidney segment of the market will grow at the fastest rate (Fig. 3). However, the intestinal segment is being boosted by iPSC-derived intestinal organoid technology with the introduction of in vitro technical advances, including CRISPR-Cas9 genome editing technology, bioengineering technology, co-culture systems with aerobic bacteria, and virus-infected disease modeling [83], which will lead to an expected average annual growth rate of up to $21.8 \%$ by 2027 . Many experts have suggested that the main reason for the current market position is due to inadequacies in health care systems, such as increasing outbreaks of recurrent infectious diseases resulting from poor sanitation, a higher rate of transmission, and insufficient public health institutions for effective management [84].

In terms of the applications of organoids, the highest share of the market in 2019 was occupied by developmental biology, followed in descending order by drug toxicity/efficacy testing, regenerative medicine, and others as of 2019 (Fig. 4) [85]. Developmental biology is the largest segment of applications in the global organoid market, and it is expected to grow at a CAGR of $22.8 \%$ by 2027 . In the organoid industry, the field of developmental biology includes a diverse range of activities, such as the production of germ lines, embryo development, and adult organogenesis. In particular, studies of patient-derived organoid biology might ac- 

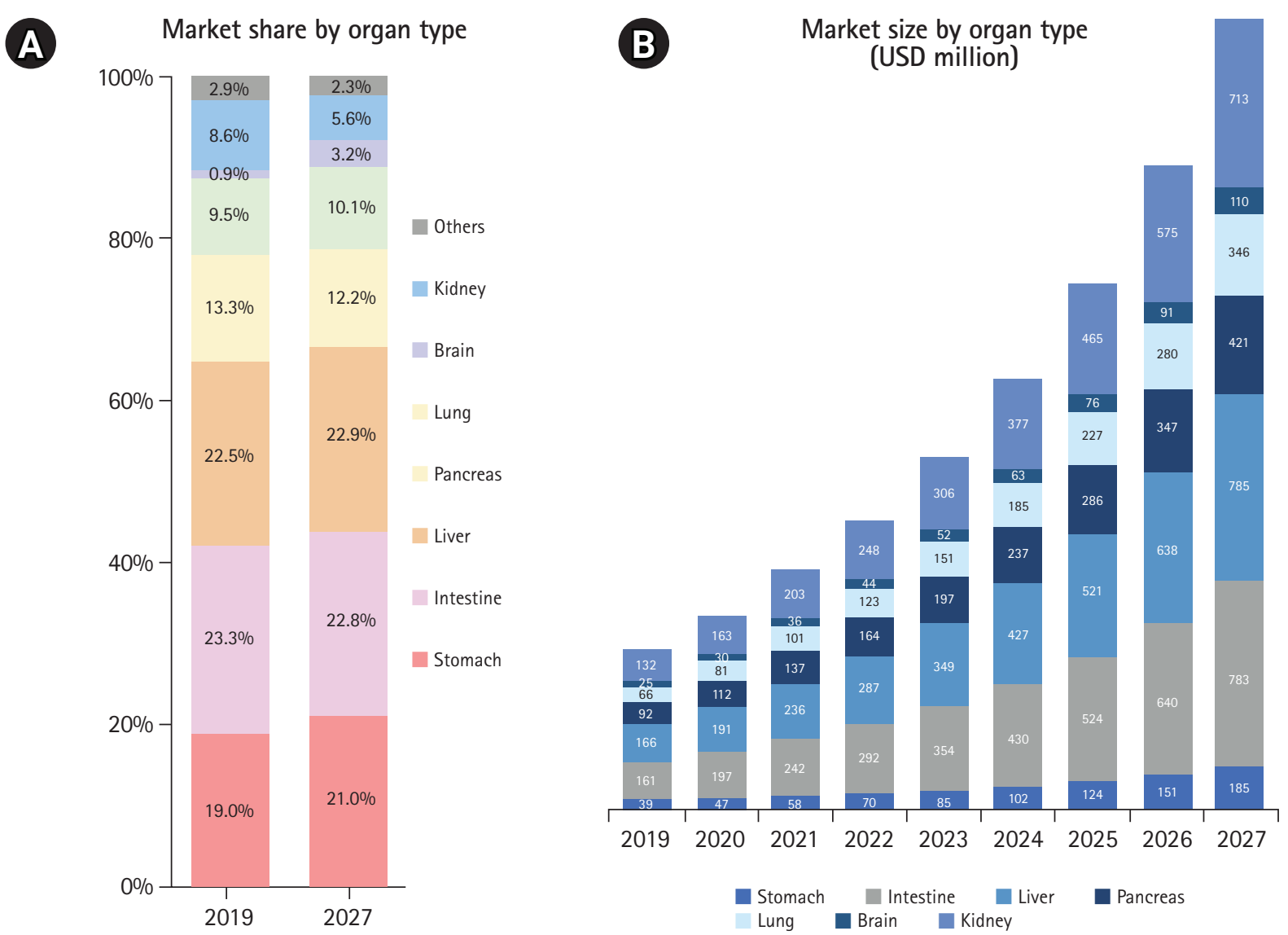

Fig. 3. Market share and size of the global organoid market by organ type. Organoids have high potential for growth in the global market. Based on organ types, the global organoid market is divided into stomach, intestine, liver, pancreas, lung, brain, kidney, and others. (A) According to market share by organ type during the forecast period from 2019 to 2027, intestine organoids dominated the global organoid market share (23.3\%) in 2019 and are expected to continue its dominance during the forecast period. The digestive system, including the liver, stomach, and pancreas, accounted for the next highest shares of the market $(22.5 \%, 19.0 \%$, and $13.3 \%$, respectively) as of 2019, and liver organoids in particular are expected to have the highest market share in 2027. (B) In an analysis of market size by organ type, intestine and liver organoids have the highest value in terms of United States dollars (USD) in 2019's global organoid market, but kidney organoids are expected to account for the highest cumulative annual growth rate in 2027.

celerate the demand for medical research, and it would create new opportunities for regenerative medicine, and lead to advances in knowledge and tools for preclinical studies, including drug development and treatment strategy. Since epidemics became one of the top 10 causes of death according to the World Health Organization in 2016, the field of disease pathology, including infectious disease, is expected to grow with a CAGR of up to $20.6 \%$ by 2027. Organoid technology has proven its effectiveness in determining the infection route, action mechanisms, and pathophysiology of diverse viral pathogens such as rotavirus, norovirus, Zika virus, and respiratory syncytial virus [86]. Furthermore, the appearance of SARS-CoV-2 has expanded funding for research and development of antiviral drugs, as well as disease modeling using organoid technology. Thus, the field of infectious disease pathology is still expected to account for a high share of the human organoid market in 2017.

As part of drug screening, the fields of drug discovery and toxicity/efficacy testing are expected to grow at CAGRs of 23\% and $21.5 \%$ by 2027 , respectively. Regarding the current drug development disadvantage of high costs and time consumption, organoid platforms are promising for drug development as a high-throughput validation platform for drugs. The field of organoid therapeutics has been applied for tissue regeneration and cell replacement, as well as ready-to-use artificial organs. For those applications, biotechnology including genetic engineering, tissue engineering, and biomaterial science are integrated into human organoids. Pharmaceutical and biotechnology companies are currently competing for success in the field of regenerative medicine 
A Market share by application type

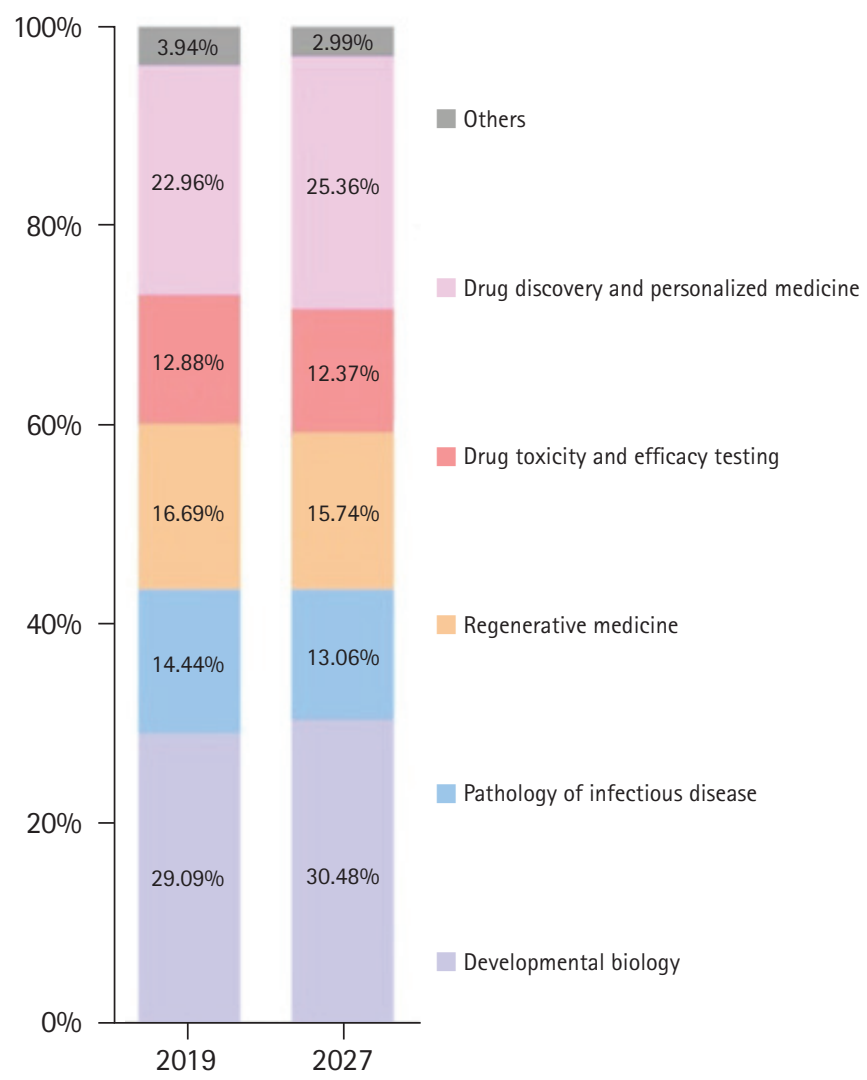

B Market size by application type (USD million)

Fig. 4. Market share and size of the global organoid market by application type. Based on application types, the global organoid market is divided into developmental biology, pathology of infectious diseases, regenerative medicine, drug toxicity and efficacy testing, drug discovery and personalized medicine, and others. (A) According to market share by application type during the forecast period from 2019 to 2027, developmental biology dominated the global organoid market share (29\%) in 2019 and is expected to continue its dominance during the forecast period. In descending order, pathology of infectious disease, regenerative medicine, drug toxicity and efficacy testing, drug discovery and personalized medicine, and others accounted for 22.9\%, 16.6\%, 14.4\%, and 12.8\% of the market share as of 2019. Notably, drug toxicity and efficacy testing are expected to have the highest rate of growth in market share by 2027. (B) In an analysis of market size by application type, developmental biology had the highest value in terms of United States dollars (USD) in the global organoid market in 2019, but drug discovery and personalized medicine are expected to account for the highest cumulative annual growth rate in 2027 [85].

with organoid technology. Thus, the use of organoids in the field of regenerative medicine will continue to grow around the world.

\section{Cases of commercializing organoid technology}

As the organoid market in various applications is expected to grow significantly, the demand for commercial human organoids will increase each year [87]. As a result, the number of companies that have commercialized organoid technology has increased, and the representative companies are as follows. Organome and Hubrecht Organoid Technology (HUB) has focused on organoid biobanking, while SUN Biosciences and System 1 Biosciences have developed a $3 \mathrm{D}$ robotic automation culture platform for organoid generation. Cellesce has provided a colorectal cancer organoid from colon cancer and breast cancer. The Living Biobank from HUB Organoid Technology has also offered a wide range of commercial organoids, CRISPR/Cas9 technology for genetic diseases with organoids, and drug response tests for clinica researchers. In addition to these organoid companies, the Human Cancer Model Initiative (HCMI) international consortium with American Type Culture Collection and HCMI recently initiated a crucial step in commercializing organoids to produce and supply cancer organoids for research [88]. Another interesting company is QGel in Lausanne, Switzerland, which has developed over 100 synthetic extracellular matrix (ECM) 

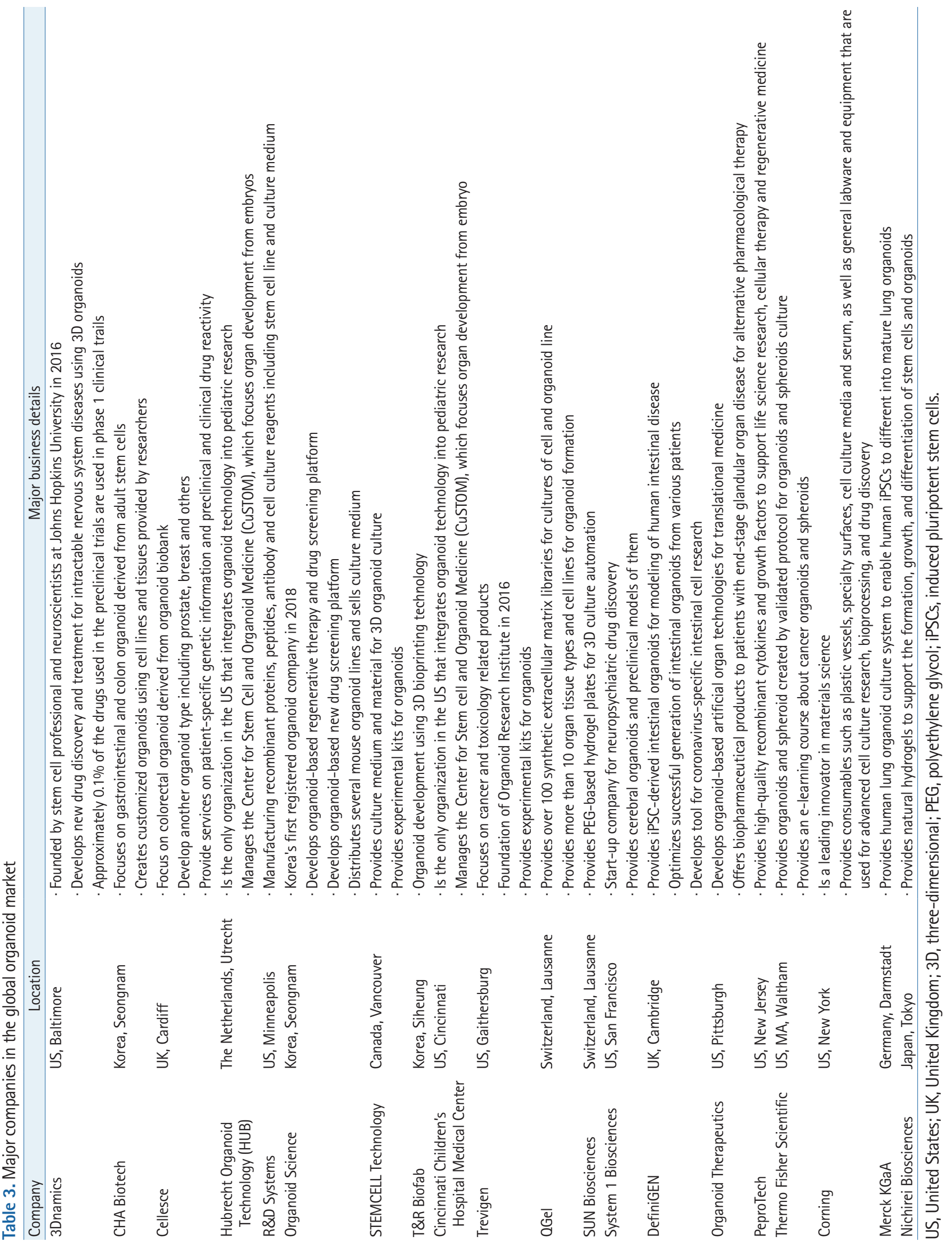

j-organoid.org 
libraries unique to each cell line and their organoid cultures [89]. Trevigen in Gaithersburg (MD, USA) has established the Organoid Resource Laboratory as its R\&D department, through which it offers ready-made gastrointestinal organoids and the technical support to generate organoids and 3D cultures. STEMCELL Technologies, Corning, and R\&D systems, as prominent key market players, have also supplied 3D engineering technology for the organoid manufacturing process. Table 3 presents a detailed summary of additional companies that have commercialized organoids and their business offerings.

\section{Living Biobank library for organoids}

The organoid biobank is a living biobank platform established by Dr. Hans Clevers as part of HUB. HUB has endeavored to be a world-leading central storage for a collection of organoids derived from both healthy donors and patients. Currently, several companies such as Epistem, Cellesce, Crown Biosciences, and STEMCELL Technologies have licensed organoid technology from the HUB. Their living organoid biobank has kept patient-derived liver, pancreatic, intestine, lung, and reproductive system organoids, as well as healthy organoids. These patient-derived organoids have been used to model major diseases such as cancer, $\mathrm{CF}$, and infectious diseases. This centralized system has directly supplied researchers, clinicians, pharmaceutical companies, and other biomaterial companies. The organoid biobank is also managed with information from organoids, including registered patient details, storage conditions, and shipping with a tracking system $[87,90]$. Another global biobank business was recently initiated by the Human Individualized Treatment for CF project in Europe, which built a large-scale intestinal organoid biobank composed of approximately 500 rare mutant biopsies of CF patients from 17 different European Union (EU) countries and in turn tested candidate drugs on organoids [91].

\section{The impacts of the COVID-19 pandemic on the global organoid market}

Organoids are a crucial tool for understanding viral pathology, which prompted researchers to use organoids to strategize regarding predictions about the COVID-19 situation and its resolution. During the COVID-19 pandemic, researchers have proven the value of human organoids, including intestine, kidney, and lung organoids, as useful research platforms against SARSCoV-2 [8]. Those results reflected the positive impact of enormous investments in R\&D related to organoids. The Canadian government provided financial support for 47 projects including the organoid industry. In Europe, the EPIORGABOLISM project of the Marie Sklodowska-Curie Actions supported human resources to study the action of SARS-CoV-2 in kidney organoids [57], and the EU government provided finding for the identification of drugs capable of blocking the early stages of SARS-CoV-2 infection. In the aspect of technical advances during the COVID-19 pandemic, a research team at Kyoto University in Japan has succeeded in creating in vitro miniature bronchi from human iPSCs that could circulate air into the alveoli [92], and this model was used for evaluating an anti-flu drug, Avigan from Fujifilm Holdings Corporation, and several new antiviral drugs for treating COVID-19 [93]. Therefore, the relationships between researchers, government, and companies have dramatically strengthened to apply organoid technology for disease modeling, virus replication, new vaccines, and drug development during the pandemic. As a result, the recent advent of SARS-CoV-2 is expected to have a positive impact on the global organoid market.

\section{Current limitations and future directions for organoid technology}

Organoid research has evolved into the formation and study of various tissue organoids along with the development of stem cell technology (Fig. 5) [94,95]. Despite the rapid advances in organoid technology, the community is facing long-term challenges for a few reasons. First, current organoid technology remains incomplete from a researcher's perspective. In detail, most organoids contain only an epithelial layer without exquisite tissue-specific microenvironments such as vascular network, immune regulatory system, and nervous system [96]. Further, the traditional organoid culture in a dish has omitted a dynamic microenvironment with nutrient and gas delivery for appropriate development, which is a limitation of completely mimicking organs and the human body [97]. Second, PSC-derived organoids have shown limited maturation compared to adult organs or tissues. Recently, 3D technology has offered the organ-on-a chip, which could reproduce the physiological and mechanical functions of human organs. This platform might be considered as an effective system to solve the immaturity of PSC-derived organoids and could be applied to diverse organs including lung, gut, brain, heart, liver, skin, and muscle [98]. Additionally, suspension cultures by bioreactors play a role as a dynamic 3D cell culture platform for a variety of biomedical applications. Their dynamic process provides a better environment to obtain large-scale organoid culture with structural and transcriptional outcomes from existing restricted workflows [99] and it facilitates organoid culture with mechanical loading of nutrients and gas concentration to fulfill organogenesis and adult develop- 
Pre-organoid Era

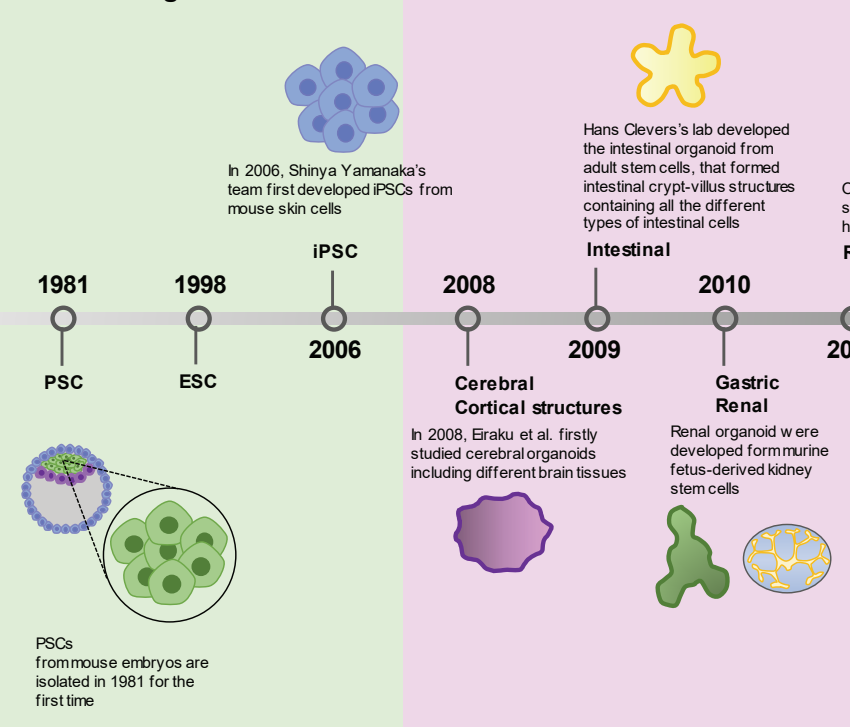

Modern Organoid Era

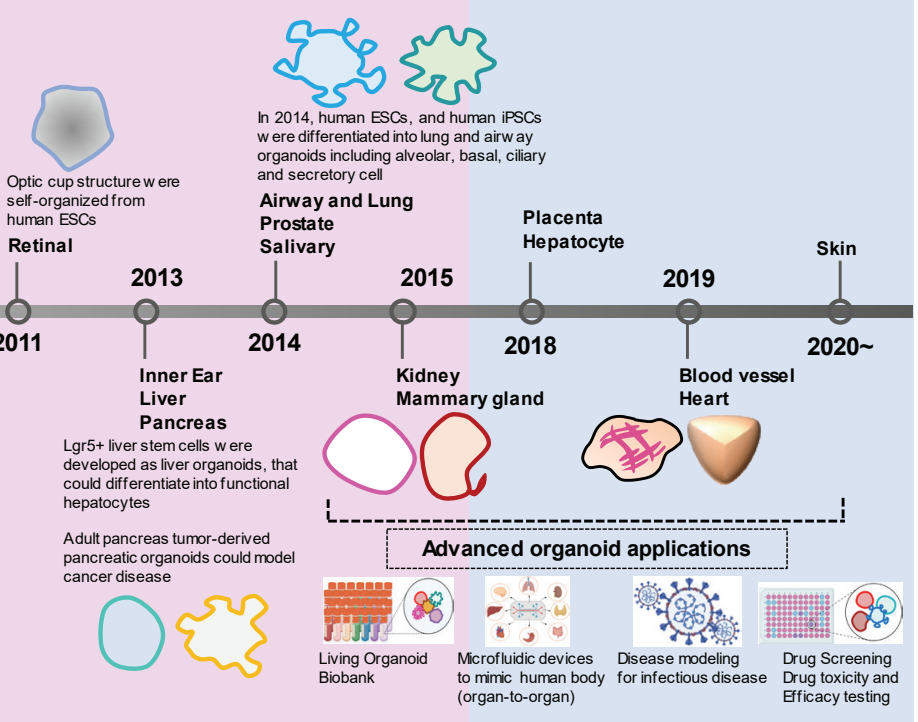

Fig. 5. The evolution of organoid technology over time. The development of stem cell research rapidly advanced in the 1980s (pre-organoid era). In 1981, researchers successfully isolated pluripotent stem cells from mouse embryos for the first time. Significantly, the development of embryonic stem cells (ESCs) by Thomson et al. [94] and later induced pluripotent stem cells (iPSCs) by Takahashi and Yamanaka et al. [95] have been milestones for accelerating the pace of organoid research. In the 2010s (modern organoid era), many researchers have designed differentiation methodologies to generate various organoid types of stem cells, which simultaneously present opportunities to study developmental biology and to model human diseases by mimicking in vivo organs at the three-dimensional level. Organoid technology has further advanced since 2015, leading to advanced organoid applications including a living organoid biobank, organ-on-a-chip, infectious disease modeling (e.g., coronavirus disease 2019), drug screening, drug toxicity and efficacy testing (advanced organoid era).

ment. To date, multiple bioreactor classes have been designed for organoid generation, expansion, and tissue-specific differentiation. These processes might accelerate the maturation of cells or organs, as well as creating a 3D multicellular construction $[99,100]$. All these proofs of concept may indicate that organson-a-chip or bioreactors will be factors in the upcoming organoid market. Another limitation is that organoid culture depends on the ECM such as Matrigel or basement membrane of animal origin. The fact that currently used matrices are normally obtained from mouse tumor cell lines could be a major obstacle for clinical applications. Moreover, organoid culture with Matrigel might affect drug penetration into organoids embedded in Matrigel, and it remains controversial for the potential use of organoids in drug screening. Therefore, a priority of $3 \mathrm{D}$ bioengineering technology is to develop novel ECM products that can replace the current ECM as soon as possible, which will further boost the growth of organoid research and market.

From the market perspective, there are a few limitations that restrain the growth of organoid market. Although it is expected that organoid technology will bring innovations in drug development and regenerative medicine, current resources, including special- ists, adequate infrastructure, and procedures, are limited. This problem may be attributed to the short experiences of research and commercializing organoid technology. Therefore, although the US, Europe, India, Japan, and Korea are leading the field of organoid technology, it is important to cultivate research specialists and skilled professionals to run, analyze, and verify research experiments to facilitate continuous growth of the organoid market globally.

\section{Conclusion}

In this review, we have presented an overview of global trends in organoid technology from research to industrial applications. As reviewed, the global market for organoids is growing significantly, and prospective organoid technology has substantial potential to provide a novel platform in various applications, including drug discovery, and developing regenerative medicine. Although organoid technology is very promising, standardization of organoid production, mass production of standardized organoids, and the development of effective cryopreservation technology for produced organoids are required for further development and 
commercialization of organoid technology. Therefore, if we overcome the limitations with a sober perspective on current obstacles facing organoid technology, tremendous social and economic benefits derived from creating organoid-related industries will be expected.

\section{Notes}

\section{Conflict of interest}

No potential conflict of interest relevant to this article was reported.

\section{Funding}

This study was supported by grants from the National Research Foundation funded by the Ministry of Science and ICT of Korea (No. 2019M3A9H1103718).

\section{Author contributions}

Conceptualization: DHW, HL; Investigation: HL, DBC, JSI; Data curation: HL, DBC, JSI; Project administration: DHW; Writing-original draft: HL; Writing-review\&editing: DHW.

\section{ORCID}

Hanbyeol Lee, https://orcid.org/0000-0001-9671-315X

Jeong Suk Im, https://orcid.org/0000-0002-5292-2803

Da Bin Choi, https://orcid.org/0000-0002-1162-8982

Dong-Hun Woo, https://orcid.org/0000-0001-7470-018X

\section{References}

1. Xu H, Jiao Y, Qin S, Zhao W, Chu Q, Wu K. Organoid technology in disease modelling, drug development, personalized treatment and regeneration medicine. Exp Hematol Oncol 2018;7:30.

2. Kim J, Koo BK, Knoblich JA. Human organoids: model systems for human biology and medicine. Nat Rev Mol Cell Biol 2020;21:571-84.

3. Lancaster MA, Knoblich JA. Organogenesis in a dish: modeling development and disease using organoid technologies. Science 2014;345:1247125.

4. Kaluthantrige Don F, Huch M. Organoids, where we stand and where we go. Trends Mol Med 2021;27:416-8.

5. Sato T, Vries RG, Snippert HJ, van de Wetering M, Barker N, Stange DE, et al. Single Lgr5 stem cells build crypt-villus structures in vitro without a mesenchymal niche. Nature 2009;459:262-5.

6. Hofer M, Lutolf MP. Engineering organoids. Nat Rev Mater

\section{$2021 ; 6: 402-20$.}

7. Lawko N, Plaskasovitis C, Stokes C, Abelseth L, Fraser I, Sharma R, et al. 3D tissue models as an effective tool for studying viruses and vaccine development. Front Mater 2021;8:80.

8. Geurts MH, van der Vaart J, Beumer J, Clevers H. The organoid platform: promises and challenges as tools in the fight against COVID-19. Stem Cell Reports 2021;16:412-8.

9. Clevers H. Modeling development and disease with organoids. Cell 2016;165:1586-97.

10. Vrij EJ, Espinoza S, Heilig M, Kolew A, Schneider M, van Blitterswijk CA, et al. 3D high throughput screening and profiling of embryoid bodies in thermoformed microwell plates. Lab Chip 2016;16:734-42.

11. Wu H, Uchimura K, Donnelly EL, Kirita Y, Morris SA, Humphreys BD. Comparative analysis and refinement of human PSC-derived kidney organoid differentiation with single-cell transcriptomics. Cell Stem Cell 2018;23:869-81.

12. McCracken KW, Catá EM, Crawford CM, Sinagoga KL, Schumacher M, Rockich BE, et al. Modelling human development and disease in pluripotent stem-cell-derived gastric organoids. Nature 2014;516:400-4.

13. van den Berg CW, Okawa S, Chuva de Sousa Lopes SM, van Iperen L, Passier R, Braam SR, et al. Transcriptome of human foetal heart compared with cardiomyocytes from pluripotent stem cells. Development 2015;142:3231-8.

14. Driehuis E, Kretzschmar K, Clevers H. Establishment of patient-derived cancer organoids for drug-screening applications. Nat Protoc 2020;15:3380-409.

15. Lancaster MA, Huch M. Disease modelling in human organoids. Dis Model Mech 2019;12:dmm039347.

16. Lancaster MA, Renner M, Martin CA, Wenzel D, Bicknell LS, Hurles ME, et al. Cerebral organoids model human brain development and microcephaly. Nature 2013;501:373-9.

17. Qian X, Song H, Ming GL. Brain organoids: advances, applications and challenges. Development 2019;146:dev166074.

18. Xiang Y, Tanaka Y, Cakir B, Patterson B, Kim KY, Sun P, et al. hESC-Derived thalamic organoids form reciprocal projections when fused with cortical organoids. Cell Stem Cell 2019;24:487-97.

19. Lee J, BÖscke R, Tang PC, Hartman BH, Heller S, Koehler KR. Hair follicle development in mouse pluripotent stem cell-derived skin organoids. Cell Rep 2018;22:242-54.

20. Koehler KR, Nie J, Longworth-Mills E, Liu XP, Lee J, Holt JR, et al. Generation of inner ear organoids containing functional hair cells from human pluripotent stem cells. Nat Biotechnol 2017;35:583-9.

21. Sui Y, Zhang S, Li Y, Zhang X, Hu W, Feng Y, et al. Generation 
of functional salivary gland tissue from human submandibular gland stem/progenitor cells. Stem Cell Res Ther 2020;11:127.

22. Takasato M, Er PX, Becroft M, Vanslambrouck JM, Stanley EG, Elefanty AG, et al. Directing human embryonic stem cell differentiation towards a renal lineage generates a self-organizing kidney. Nat Cell Biol 2014;16:118-26.

23. Takasato M, Er PX, Chiu HS, Maier B, Baillie GJ, Ferguson $\mathrm{C}$, et al. Kidney organoids from human iPS cells contain multiple lineages and model human nephrogenesis. Nature 2016;536:238.

24. Freedman BS, Brooks CR, Lam AQ, Fu H, Morizane R, Agrawal V, et al. Modelling kidney disease with CRISPR-mutant kidney organoids derived from human pluripotent epiblast spheroids. Nat Commun 2015;6:8715.

25. Hofbauer P, Jahnel SM, Papai N, Giesshammer M, Deyett A, Schmidt C, et al. Cardioids reveal self-organizing principles of human cardiogenesis. Cell 2021;184:3299-317.

26. Nugraha B, Buono MF, von Boehmer L, Hoerstrup SP, Emmert MY. Human cardiac organoids for disease modeling. Clin Pharmacol Ther 2019;105:79-85.

27. Filippo Buono M, von Boehmer L, Strang J, Hoerstrup SP, Emmert MY, Nugraha B. Human cardiac organoids for modeling genetic cardiomyopathy. Cells 2020;9:1733.

28. Wimmer RA, Leopoldi A, Aichinger M, Wick N, Hantusch B, Novatchkova M, et al. Human blood vessel organoids as a model of diabetic vasculopathy. Nature 2019;565:505-10.

29. Zhang S, Wan Z, Kamm RD. Vascularized organoids on a chip: strategies for engineering organoids with functional vasculature. Lab Chip 2021;21:473-88.

30. Li Y, Wu Q, Sun X, Shen J, Chen H. Organoids as a powerful model for respiratory diseases. Stem Cells Int 2020; 2020:5847876.

31. Katsura H, Sontake V, Tata A, Kobayashi Y, Edwards CE, Heaton $\mathrm{BE}$, et al. Human lung stem cell-based alveolospheres provide insights into SARS-CoV-2-mediated interferon responses and pneumocyte dysfunction. Cell Stem Cell 2020;27:890904.

32. Wang Y, Kim R, Gunasekara DB, Reed MI, DiSalvo M, Nguyen DL, et al. Formation of human colonic crypt array by application of chemical gradients across a shaped epithelial monolayer. Cell Mol Gastroenterol Hepatol 2017;5:113-30.

33. Eiraku M, Takata N, Ishibashi H, Kawada M, Sakakura E, Okuda S, et al. Self-organizing optic-cup morphogenesis in three-dimensional culture. Nature 2011;472:51-6.

34. Pompaiah M, Bartfeld S. Gastric organoids: an emerging model system to study Helicobacter pylori pathogenesis. Curr Top Microbiol Immunol 2017;400:149-68.
35. Garcez PP, Loiola EC, Madeiro da Costa R, Higa LM, Trindade $\mathrm{P}$, Delvecchio R, et al. Zika virus impairs growth in human neurospheres and brain organoids. Science 2016;352: $816-8$

36. Sutarjono B. Can we better understand how Zika leads to microcephaly? A systematic review of the effects of the Zika virus on human brain organoids. J Infect Dis 2019;219:734-45.

37. Xu M, Lee EM, Wen Z, Cheng Y, Huang WK, Qian X, et al. Identification of small-molecule inhibitors of Zika virus infection and induced neural cell death via a drug repurposing screen. Nat Med 2016;22:1101-7.

38. Zhou J, Li C, Sachs N, Chiu MC, Wong BH, Chu H, et al. Differentiated human airway organoids to assess infectivity of emerging influenza virus. Proc Natl Acad Sci U S A 2018; 115:6822-7.

39. Schwank G, Koo BK, Sasselli V, Dekkers JF, Heo I, Demircan T, et al. Functional repair of CFTR by CRISPR/Cas9 in intestinal stem cell organoids of cystic fibrosis patients. Cell Stem Cell 2013;13:653-8.

40. Fordham RP, Yui S, Hannan NR, Soendergaard C, Madgwick A, Schweiger PJ, et al. Transplantation of expanded fetal intestinal progenitors contributes to colon regeneration after injury. Cell Stem Cell 2013;13:734-44.

41. Nakano T, Ando S, Takata N, Kawada M, Muguruma K, Sekiguchi K, et al. Self-formation of optic cups and storable stratified neural retina from human ESCs. Cell Stem Cell 2012; 10:771-85.

42. Lee J, Rabbani CC, Gao H, Steinhart MR, Woodruff BM, Pflum ZE, et al. Hair-bearing human skin generated entirely from pluripotent stem cells. Nature 2020;582:399-404.

43. Huch M, Gehart H, van Boxtel R, Hamer K, Blokzijl F, Verstegen MM, et al. Long-term culture of genome-stable bipotent stem cells from adult human liver. Cell 2015;160:299-312.

44. Huang L, Desai R, Conrad DN, Leite NC, Akshinthala D, Lim $\mathrm{CM}$, et al. Commitment and oncogene-induced plasticity of human stem cell-derived pancreatic acinar and ductal organoids. Cell Stem Cell 2021;28:1090-104.

45. Cruz-Acuña R, Quirós M, Farkas AE, Dedhia PH, Huang S, Siuda D, et al. Synthetic hydrogels for human intestinal organoid generation and colonic wound repair. Nat Cell Biol 2017;19:1326-35.

46. Chua CW, Shibata M, Lei M, Toivanen R, Barlow LJ, Bergren SK, et al. Single luminal epithelial progenitors can generate prostate organoids in culture. Nat Cell Biol 2014;16:951-61. $1-4$.

47. Lee J, Sutani A, Kaneko R, Takeuchi J, Sasano T, Kohda T, et al. In vitro generation of functional murine heart organoids via 
FGF4 and extracellular matrix. Nat Commun 2020;11:4283.

48. Sugimoto S, Ohta Y, Fujii M, Matano M, Shimokawa M, Nanki K, et al. Reconstruction of the human colon epithelium in vivo. Cell Stem Cell 2018;22:171-6.

49. Gjorevski N, Sachs N, Manfrin A, Giger S, Bragina ME, Ordóñez-Morán P, et al. Designer matrices for intestinal stem cell and organoid culture. Nature 2016;539:560-4.

50. Mondrinos MJ, Jones PL, Finck CM, Lelkes PI. Engineering de novo assembly of fetal pulmonary organoids. Tissue Eng Part A 2014;20:2892-907.

51. Rossi G, Manfrin A, Lutolf MP. Progress and potential in organoid research. Nat Rev Genet 2018;19:671-87.

52. Kedinger M, Duluc I, Fritsch C, Lorentz O, Plateroti M, Freund JN. Intestinal epithelial-mesenchymal cell interactions. Ann NY Acad Sci 1998;859:1-17.

53. Ettayebi K, Crawford SE, Murakami K, Broughman JR, Karandikar U, Tenge VR, et al. Replication of human noroviruses in stem cell-derived human enteroids. Science 2016; 353:1387-93.

54. Finkbeiner SR, Zeng XL, Utama B, Atmar RL, Shroyer NF, Estes MK. Stem cell-derived human intestinal organoids as an infection model for rotaviruses. mBio 2012;3:e00159-12.

55. Engevik MA, Engevik KA, Yacyshyn MB, Wang J, Hassett DJ, Darien B, et al. Human Clostridium difficile infection: inhibition of NHE3 and microbiota profile. Am J Physiol Gastrointest Liver Physiol 2015;308:G497-509.

56. Heo I, Dutta D, Schaefer DA, Iakobachvili N, Artegiani B, Sachs N, et al. Modelling Cryptosporidium infection in human small intestinal and lung organoids. Nat Microbiol 2018;3:814-23.

57. Monteil V, Kwon H, Prado P, Hagelkrüys A, Wimmer RA, Stahl M, et al. Inhibition of SARS-CoV-2 infections in engineered human tissues using clinical-grade soluble human ACE2. Cell 2020;181:905-13.

58. Lamers MM, Beumer J, van der Vaart J, Knoops K, Puschhof J, Breugem TI, et al. SARS-CoV-2 productively infects human gut enterocytes. Science 2020;369:50-4.

59. Hoffmann M, Kleine-Weber H, Schroeder S, Krüger N, Herrler T, Erichsen S, et al. SARS-CoV-2 cell entry depends on ACE2 and TMPRSS2 and is blocked by a clinically proven protease inhibitor. Cell 2020;181:271-80.

60. Tavcar P, Potokar M, Kolenc M, Korva M, Avsic-Zupanc T, Zorec R, et al. Neurotropic viruses, astrocytes, and COVID-19. Front Cell Neurosci 2021; 15:662578.

61. Nie YZ, Zheng YW, Miyakawa K, Murata S, Zhang RR, Sekine $\mathrm{K}$, et al. Recapitulation of hepatitis B virus-host interactions in liver organoids from human induced pluripotent stem cells. EBioMedicine 2018;35:114-23.

62. Schutgens F, Rookmaaker MB, Margaritis T, Rios A, Ammerlaan C, Jansen J, et al. Tubuloids derived from human adult kidney and urine for personalized disease modeling. Nat Biotechnol 2019;37:303-13.

63. Chua A, Ananthanarayanan A, Ong J, Wong JY, Yip A, Singh $\mathrm{NH}$, et al. Hepatic spheroids used as an in vitro model to study malaria relapse. Biomaterials 2019;216:119221.

64. Tuveson D, Clevers H. Cancer modeling meets human organoid technology. Science 2019;364:952-5.

65. Botti G, Di Bonito M, Cantile M. Organoid biobanks as a new tool for pre-clinical validation of candidate drug efficacy and safety. Int J Physiol Pathophysiol Pharmacol 2021;13:17-21.

66. Dijkstra KK, Cattaneo CM, Weeber F, Chalabi M, van de Haar J, Fanchi LF, et al. Generation of tumor-reactive T cells by co-culture of peripheral blood lymphocytes and tumor organoids. Cell 2018;174:1586-98.

67. Huang L, Bockorny B, Paul I, Akshinthala D, Frappart PO, Gandarilla O, et al. PDX-derived organoids model in vivo drug response and secrete biomarkers. JCI Insight 2020; 5:e135544.

68. Claussnitzer M, Cho JH, Collins R, Cox NJ, Dermitzakis ET, Hurles ME, et al. A brief history of human disease genetics. Nature 2020;577:179-89.

69. Firth AL, Menon T, Parker GS, Qualls SJ, Lewis BM, Ke E, et al. Functional gene correction for cystic fibrosis in lung epithelial cells generated from patient iPSCs. Cell Rep 2015;12:1385-90.

70. Yang KC, Breitbart A, De Lange WJ, Hofsteen P, Futakuchi-Tsuchida A, Xu J, et al. Novel adult-onset systolic cardiomyopathy due to MYH7 E848G mutation in patient-derived induced pluripotent stem cells. JACC Basic Transl Sci 2018;3:728-40.

71. Long C, Li H, Tiburcy M, Rodriguez-Caycedo C, Kyrychenko V, Zhou H, et al. Correction of diverse muscular dystrophy mutations in human engineered heart muscle by single-site genome editing. Sci Adv 2018;4:eaap9004.

72. Kita Y, Hamada A, Saito R, Teramoto Y, Tanaka R, Takano $\mathrm{K}$, et al. Systematic chemical screening identifies disulfiram as a repurposed drug that enhances sensitivity to cisplatin in bladder cancer: a summary of preclinical studies. Br J Cancer 2019;121:1027-38.

73. Lampis A, Carotenuto P, Vlachogiannis G, Cascione L, Hedayat S, Burke R, et al. MIR21 drives resistance to heat shock protein 90 inhibition in cholangiocarcinoma. Gastroenterology 2018; 154:1066-79.

74. Koppens MA, Bounova G, Cornelissen-Steijger P, de Vries N, 
Sansom OJ, Wessels LF, et al. Large variety in a panel of human colon cancer organoids in response to EZH2 inhibition. Oncotarget 2016;7:69816-28.

75. Low LA, Mummery C, Berridge BR, Austin CP, Tagle DA. Organs-on-chips: into the next decade. Nat Rev Drug Discov 2021;20:345-61.

76. Hu H, Gehart H, Artegiani B, LÖpez-Iglesias C, Dekkers F, Basak $\mathrm{O}$, et al. Long-term expansion of functional mouse and human hepatocytes as 3D organoids. Cell 2018;175:1591606.

77. Yoshihara E, O'Connor C, Gasser E, Wei Z, Oh TG, Tseng TW, et al. Immune-evasive human islet-like organoids ameliorate diabetes. Nature 2020;586:606-11.

78. Zhang YS, Arneri A, Bersini S, Shin SR, Zhu K, Goli-Malekabadi $Z$, et al. Bioprinting 3D microfibrous scaffolds for engineering endothelialized myocardium and heart-on-a-chip. Biomaterials 2016;110:45-59.

79. Creff J, Courson R, Mangeat T, Foncy J, Souleille S, Thibault C, et al. Fabrication of 3D scaffolds reproducing intestinal epithelium topography by high-resolution 3D stereolithography. Biomaterials 2019;221:119404.

80. Li Y, Tang P, Cai S, Peng J, Hua G. Organoid based personalized medicine: from bench to bedside. Cell Regen 2020;9:21.

81. BCC Research. Organoids market: global industry analysis 2014-2018 \& opportunity assessment 2019-2029 [Internet]. BCC Research; 2019 Sep [cited 2021 Aug 31]. Available from: https://www.bccresearch.com/partners/future-markets-insights/organoids-market.html.

82. National Biotech Policy Research Center. [Trend and prospect on Organoid market]. BioINdustry No.101 [Internet]. Daejeon: National Biotech Policy Research Center; 2021 [cited 2021 Aug 25]. Available from: https://www.bioin.or.kr/ board.do;jsessionid=CB77217882DF8F58B3C1D267CE6859 B3 ? num $=258734 \& \mathrm{cmd}=$ view $\&$ bid $=$ watch $\& \mathrm{cPage}=6 \&-$ cate $1=$ all \&cate $2=$ all2\&s_key $=\& s \_s t r=\&$ sdate $=\&$ edate $=$.

83. MarketWatch. Organoids market trends insights and forecast research 2021-2027 | business analysis, competition strategies, opportunities and share demand, global size and future investment analysis with Covid-19 impact [Internet]. MarketWatch; 2021 Aug 25 [cited 2021 Aug 25]. Available from: https://www.marketwatch.com/press-release/organoids-market-trends-insights-and-forecast-research-2021-2027-business-analysis-competition-strategies-opportunities-and-share-demand-global-size-and-futureinvestment-analysis-with-covid-19-impact-2021-08-25.

84. Hentschel V, Arnold F, Seufferlein T, Azoitei N, Kleger A, Müller M. Enteropathogenic infections: organoids go bacteri- al. Stem Cells Int 2021;2021:8847804.

85. An JY. [Trend on Organoid market]. Bio Econ Brief 2019;72: $1-6$.

86. Sridhar A, Simmini S, Ribeiro C, Tapparel C, Evers MM, Pa$j$ krt $D$, et al. A perspective on organoids for virology research. Viruses 2020;12:1341.

87. Takebe T, Wells JM, Helmrath MA, Zorn AM. Organoid center strategies for accelerating clinical translation. Cell Stem Cell 2018;22:806-9.

88. American Type Culture Collection (ATCC). Revolutionizing cancer research with next-generation 2-D and 3-D patient-derived cancer models [Internet]. ATCC [cited 2021 Aug 25]. Available from: https://www.atcc.org/cell-products/collections-and-projects/human-cancer-models-initiative\#t=productTab\&numberOfResults $=12$.

89. Bergenheim F, Fregni G, Buchanan CF, Riis LB, Heulot M, Touati J, et al. A fully defined 3D matrix for ex vivo expansion of human colonic organoids from biopsy tissue. Biomaterials 2020;262:120248.

90. Kimura M, Azuma M, Zhang RR, Thompson W, Mayhew CN, Takebe T. Digitalized human organoid for wireless phenotyping. iScience 2018;4:294-301.

91. van Mourik P, Michel S, Vonk AM, Beekman JM, van der Ent CK, De Keyser H, et al. Rationale and design of the HIT-CF organoid study: stratifying cystic fibrosis patients based on intestinal organoid response to different CFTR-modulators. Transl Med Commun 2020;5:9.

92. The Japan Times. Japan researchers create tiny bronchi to develop drug for COVID-19 [Internet]. The Japan Times; 2020 Jun 3 [cited 2020 Jun 3]. Available from: https://www. japantimes.co.jp/news/2020/06/03/national/science-health/ japan-bronchi-drug-coronavirus/.

93. Tu YF, Chien CS, Yarmishyn AA, Lin YY, Luo YH, Lin YT, et al. A review of SARS-CoV-2 and the ongoing clinical trials. Int J Mol Sci 2020;21:2657.

94. Thomson JA, Itskovitz-Eldor J, Shapiro SS, Waknitz MA, Swiergiel JJ, Marshall VS, et al. Embryonic stem cell lines derived from human blastocysts. Science 1998;282:1145-7.

95. Takahashi K, Yamanaka S. Induction of pluripotent stem cells from mouse embryonic and adult fibroblast cultures by defined factors. Cell 2006; 126:663-76.

96. Jabs J, Zickgraf FM, Park J, Wagner S, Jiang X, Jechow K, et al. Screening drug effects in patient-derived cancer cells links organoid responses to genome alterations. Mol Syst Biol 2017; 13:955.

97. Song G, Zhao M, Chen H, Zhou X, Lenahan C, Ou Y, et al. The application of brain organoid technology in stroke re- 
search: challenges and prospects. Front Cell Neurosci 2021; 15:646921.

98. Lee SJ, Lee HA. Trends in the development of human stem cell-based non-animal drug testing models. Korean J Physiol Pharmacol 2020;24:441-52.
99. Phelan MA, Lelkes PI, Swaroop A. Mini and customized low-cost bioreactors for optimized high-throughput generation of tissue organoids. Stem Cell Investig 2018;5:33.

100. Velasco V, Shariati SA, Esfandyarpour R. Microtechnology-based methods for organoid models. Microsyst Nanoeng 2020;6:76. 